\title{
Do juizo arbitral *
}

\author{
Alfredo Buzaid \\ Catedrático de Direito Judiciário Civil da \\ Faculdade de Direito da Universidade de \\ São Paulo.
}

\section{História}

1. O instituto do juízo arbitral é conhecido e praticado desde a mais remota antiguidade. Nossa investigação começa, porém, no direito romano, onde a matéria foi regulada com precisão no Digesto, liv. IV, título 8 e no Código, liv. II, tít. 55, sob a epígrafe De Receptis. Os documentos relativos ao período mais antigo deitam pouca luz e a sua invocação tem um valor muito relativo.

Paulo dizia que as partes podiam celebrar compromisso, à semelhança do juízo comum, afim de submeter as suas pendências a um terceiro, denominado árbitro:

Dig. liv. 8, 1: Compromissum ad similitudinem iudiciorum redigitur et ad finiendas lites pertinet. $\mathrm{O}$ ato do árbitro consistente em aceitar o encargo se denominava

* Prova escrita do Prof. Alfredo Buzaid, no concurso à cátedra de Direito Judiciário Civil, iniciado a 15 de março de 1958. A Comissão Julgadora foi integrada pelos professôres Jorge Americano e Luís Eulálio de Bueno Vidigal, indicados pela Congregação, Amilcar de Castro da Universidade de Minas Gerais, L. A. da Costa Carvalho da Universidade do Brasil e Alcides de Mendonça Lima da Universidade do Rio Grande do Sul, escolhidos pelo Conselho Técnico e Administrativo. 
arbitrium recipere e o julgamento recebia a designação de sententia (cit. Dig. IV, 8.3).

As partes estabeleciam uma pena pelo descumprimento do julgado, de caráter pecuniário; mas diferente da sententia, da qual nascia a actio iudicati, o julgado proferido pelo árbitro só conferia uma actio in factum.

$\mathrm{O}$ árbitro escolhido pelas partes mediante compromisso é bem distinto do designado pelo pretor no sistema do ordo iudiciorum privatorum, embora seja certo que àquele tempo a justiça era, em ambos os casos, privada. Não se há de perder de vista o caráter contratual, já assinalado por Ulpiano no

Dig. 15.1.3, § 11: sicut in stipulatione. ita judicio contrahi.

Apesar de o Digesto ser rico de disposições relativas à constituição do juízo, alegação de suspeição, forma do julgamento, época em que devia ser feito e sanções aplicáveis, sabe-se que Justiniano introduziu algumas modificações, que vieram complicar o sistema ao invés de facilitar a sua realização prática.

2. As linhas fundamentais do instituto passaram para o direito intermédio e os juristas medievais procuraram estudar a natureza do juízo arbitral, formando-se três doutrinas fundamentais: uma que o considera autêntica jurisdição; outra, que lhe nega caráter jurisdicional; e uma terceira, que lhe atribui função jurisdicional derivada. Longas e brilhantes foram as polêmicas dos autores, destacando-se entre êles Paulo de Castro, que sempre negou caráter jurisdicional ao juízo arbitral.

Antes destas controvérsias doutrinárias, já o Código Visigótico havia consagrado o instituto, como se pode ver no livro II, tít. I, lei n. ${ }^{\circ}$ XIII do Rei Recesvindo:

Dirimere causas nulli licebit, nisi aut a principibus potestate concessa, aut ex consensum partium electo iudice trium testium fuerit electionis pactio signis, vel subscriptionibus roborata.

A invocação dêsse texto tem importância para o direito português, porque o Forum Iudicium foi o direito vigente na 
Península hispânica por largo tempo, antes que Portugal fôsse elevado a Reino. Mas a evolução não se interrompe depois da fundação da monarquia lusitana. Já os primeiros reis legislaram amplamente sôbre a matéria. D. AFonso III publicou lei sôbre os "juyses aluvdores", como se pode ver nos Portugaliae Monumenta Historica, Leges et Consuetudines, vol. I, fascículo II, p. 272 e seg.

As disposições passam, consideràvelmente melhoradas, para as Ordenações Afonsinas (liv. II, tít. 113), Manuelinas (liv. III, tít. 81) e Filipinas (liv. II, tít. 16).

O Regulamento 737 de 25 de novembro de 1850 regulou a matéria a partir do art. 411, mas o Decreto n. ${ }^{\circ} 3.900$ de 26 de junho de 1867 aboliu o juízo arbitral necessário, estabelecido pelo art. 20, título único do Código Comercial, mantendo o juízo arbitral voluntário.

No período republicano, os Códigos estaduais 'mantiveram o instituto que hoje é disciplinado pelo Código Nacional no livro IX, a partir do art. 1.031.

\section{II}

\section{Direito comparado}

3. No direito estrangeiro, os Códigos das nações civilizadas the dedicam capítulos especiais. Assim o da Alemanha ( $\$ \$ 1.025$ e segs.); da França (art. 1.003 e segs.); da Holanda (art. 620 e segs.); da Itália (art. 806 e segs.); da Áustria (art. 577 e segs.) e de Portugal (art. 1.566 e segs.).

Em outros países constitui objeto de lei especial. Assim na Inglaterra o Arbitration Act de 1950; na Suécia, a lei de 14 de junho de 1929; nos Estados Unidos o Arbitration Federal Act, baixado a 12 de fevereiro de 1925 , cap. $213, \S 15$, em vigor desde 1 de janeiro de 1926; e na Rússia Soviética, apêndice ao cap. XXII do Código de Processo Civil, mandado incluir, conforme resolução da Comissão Central Executiva de 16 de outubro de 1924 . 


\section{III}

\section{Teoria do juízo arbitral}

4. Quando surge um conflito de interêsses, as partes, de ordinário, o submetem ao Poder Judiciário; mas a composição na lide não se dá apenas através dos órgãos jurisdicionais. As partes podem, nos casos previstos em lei, escolher um ou mais árbitros, afim de resolverem a sua pendência. Semelhante juízo, que é instituído mediante compromisso, tem a função de equivalente jurisdicional.

Chama-se compromisso o ato pelo qual as partes capazes de contratar podem louvar-se em árbitros, mediante documento escrito, afim de que resolvam uma controvérsia. o compromisso se distingue da transação. Esta é um contrato pelo qual os interessados, mediante recíprocas concessões, previnem ou terminam um litígio. O compromisso, ao contrário, institui um juízo para resolvê-lo. Nada concedem reciprocamente. Aguardam um julgamento, que será o juízo normativo para a sua conduta futura.

5. O instituto do compromisso está intimamente ligado ao do juízo arbitral, porque é um meio em relação a um fim. Não deve, porém, ser confundido com certas cláusulas compromissórias, que as partes inserem nos contratos, cujo conteúdo é indeterminado não só em relação ao objeto, como principalmente quanto aos árbitros, cujos nomes, sobrenomes e domicílios devem figurar no ato de celebração do compromisso (Cód. Civ. art. 1.039). Semelhantes cláusulas são desprovidas de eficácia para o fỉm de excepcionar o juízo comum, impedindo o conhecimento da matéria que lhe é submetida a julgamento.

6. O objetivo do compromisso é a instituição do juizo arbitral. Pode ser judicial ou extrajudicial. A sua função é resolver pendências judiciais ou conflitos de interêsses ainda não submetidos ao Poder Judiciário. Todavia não se admite juízo arbitral depois de proferida decisão em 
qualquer instância (Cod. Proc. Civ. art. 1.035, § único). Isso significa que, celebrado o compromisso na pendência sujeita aos órgãos da jurisdição ordinária é admissível sòmente enquanto êstes ainda não proferiram julgamento.

o compromisso pode declarar o prazo em que deve ser dada a decisão arbitral, conter a autorização para que os árbitros julguem por equidade e facultar que escolham terceiro árbitro, caso divirjam, se as partes o não tiveram nomeado (Cod. Civ. art. 1.040).

7. Qual a natureza do juízo arbitral? Dentre as várias doutrinas, merecem ressaltar-se três principais: a de Mortara, a de Alfredo Rocco e a de Chiovenda. O primeiro procurou elaborar uma concepção publicística, vendo no juízo arbitral duas fases: uma que se forma entre as partes e tem natureza privada; outra que se forma entre os árbitros e o Estado e tem natureza jurisdicional. $O$ que importa é considerar esta segunda fase, que configura um mandato pelo qual os árbitros são investidos de poder jurisdicional.

As idéias expostas por Mortara ganharam maior desenvolvimento no pensamento de Hugo Rocco, constante de seu livro sôbre a Autoridade da Coisa Julgada e seus limites subjetivos (p. 70 e segs.). Este último autor, considerando que no juri, como noutros institutos, há o exercício privado de uma função pública, estabelece uma semelhanca com o juízo arbitral, considerado como exercício de função jurisdicional. Despreza a idéia de mandato, que constitui a base do pensamento de Mortara, mas vincula os árbitros à uma função paralela a que exercem os juízes na atividade jurisdicional.

8. Alfredo Rocco, diversamente de Mortara e de seu irmão Hugo Rocco, considera o juízo arbitral de natureza nitidamente privada. Do mesmo modo que, na compra e venda, a fixação do preço pode ser deixada ao arbítrio de terceiro (Cód. Civ. bras., art. 1.123), assim no juízo arbitral as partes interessadas podem escolher uma pessoa desinteressada, cuja função precípua é a de integrar a von- 
tade incompleta; ou, em outras palavras, a vontade das partes é indeterminada, mas deferminável; o juízo arbitral preenche a missão de completar o elemento volitivo, que faltou para a integração do ato jurídico.

Alfredo Roccio assume, dêste modo, uma posição privatística em contraposto à posição de Mortara e de Hugo Rocco, que sustentam o caráter jurisdicional dos árbitros.

9. Uma poșição, diferente das duas primeiras já expostas, toma Chrovenda em seus princípios e mais recentemente nas suas Instituições de Direito Processual Civil. O que a caracteriza é o senso de equilíbrio e a clara percepção da realidade. O fenômeno do juízo arbitral não configura o exercício de poderes jurisdicionais, porque os árbitros não podem coativamente ouvir testemunhas e praticar demais atos que são inerentes aos magistrados. Por outro lado, há legislações que condicionam a exequibilidade do laudo arbitral à homologação pelo Poder Judiciário, o que significa que só por êsse ato é que êle recebe o cunho de autoridade do Estado. Antes disso se assemelha a um parecer. Os árbitros não atuam a vontade concreta da lei no sentido em que esta expressão é empregada, porque não lhes é lícito impor sanções. Em conclusão, o juízo arbitæal é um julgamento, que só se aperfeiçoa quando recebe a fôrça e autoridade do Estado. Portanto não é atividade jurisdicional.

\section{IV}

o juízo arbitral no sistema do código de processo civil

10. O Código de Processo Civil regulou exaustivamente o juízo arbitral (art. 1031 usque 1.046).

Quem pode ser árbitro

Podem servir como árbitros tôdas as pessoas, salvo aquelas expressamente excluidas pela lei. Assim não po- 
dem ser árbitros os incapazes, os analfabetos e os estrangeiros. Este dispositivo reproduziu parcialmente preceito contido no Código de Processo de Minas Gerais. Mas neste, a proibição relativa aos estrangeiros não era absoluta. Abrangia apenas os que não soubessem o idioma nacional. O legislador federal, porém, consignou proibição absoluta. o Prof. Amilcar de Castro criticou a disposição, inclinando-se de lege ferenda pelo sistema do Código de Minas.

Da instituição do juizo

Os árbitros devem, no prazo de 10 dias, declarar se aceitamı a nomeação, presumindo-se a recusa do que, interpelado, não responder. No caso de falta, impedimento ou recusa de qualquer dos árbitros, será convocado o substituto (Cod. Proc. Civ. art. 1.032).

Ninguém é obrigado a ser árbitro. Êste princípio já vem do direito romano: Dig. 4.8.3: Tametsi, neminem praeter cogat arbitrium recipere, quoniam haec res libera et soluta est et extra necessitatem jurisdictionis posita...

Mas se o árbitro aceita a nomeação, assume função análoga à do juiz. É terceiro desinteressado chamado a decidir um conflito que surge entre dois interessados. Por isso deve ser imparcial e não ter impedimento. Às partes que lhe pedem uma apreciação imparcial é lícito argüir a sua suspeição ou impedimento, na forma do livro II, título V, capítulo I e II do Código.

Instituído o juízo, funciona como escrivão um dos árbitros, se outra pessoa não fôr designada no compromisso (Cod. Proc. Civ. art. 1.034).

\section{Do processo e julgamento}

11. Os árbitros concedem às partes o prazo comum de dez dias para a apresentação de alegações e documentos. Em igual prazo e também comum, podem as partes dizer sôbre as alegações apresentadas. As alegações e documentos serão acompanhados de cópias, que o escrivão entregarả aos árbitros e à parte adversa, autuando os originais. 
O escrivão organiza os autos do processo. Quando o compromisso é celebrado na pendência de lide, os autos serão entregues aos árbitros, mediante recibo e independentemente de traslado, prosseguindo-se nele.

O juizo arbitral se desenvolve em audiência, na qual se procede à instrução e se segue o debate, que se realizará com a presença das partes; o relator designado marcará outra audiência para a publicação da sentença (Cod. Proc. Civ. art. 1.036).

\section{Do laudo}

12. O laudo é deliberado em conferência por maioria de votos e em seguida reduzido a escrito por um dos árbitros. Havendo empate, o árbitro desempatador será convocado para, no prazo de vinte dias, adotar uma das decisões (Cod. Proc. Civ. art. 1.037). O texto legal parece indicar a obrigação de o terceiro desempatador adotar um dos votos. Pode ocorrer, porém, que não esteja convencido da procedência de nenhum.

A lei não pode impor que alguém julgue contra a sua convicção. Embora não estivesse tal caso indicado entre os que acarretam a extinção do compromisso, parece-nos que essa é a consequência lógica.

13. O laudo tem caráter de sentença e por isso deve conter a indicação das partes, do ato do compromisso, exposição sumária dos motivos e a decisão, com a indicação da data em que foi proferida e a assinatura de todos os árbitros. Será, no entanto, válido o laudo assinado pela maioria, uma vez que assim hajam todos resolvido em conferência (Cod. Proc. Civ. art. 1.038).

\section{Extinção do compromisso}

14. O compromisso fica sem efeito: I) se os árbitros divergirem quanto à nomeação do desempatador, de modo que nenhum obtenha maioria absoluta; II) em caso de recusa de qualquer dos árbitros, ou de seu substituto, antes 
de aceita a nomeação; III) se houver empate no julgamento, sem que tenham as partes nomeado desempatador ou autorizado a sua nomeação; IV) no caso de dispersão de votos, sem que qualquer dêles tenha maioria; V) quando a decisão não fôr proferida dentro do prazo marcado no compromisso ou fixado na lei; VI) se falecer qualquer das partes, deixando herdeiro incapaz; VII) se qualquer dos árbitros falecer ou ficar impossibilitado de dar a sua decisão, e não houver substituto.

\section{Da homologaç̃o}

15. A execução da sentença arbitral depende de homologação. Será competente o juiz a que, originàriamente, competir o julgamento da causa. No prazo de cinco dias, contados da data da assinatura do laudo, êste será depositado no cartório do juiz competente para a homologação. Feito o depósito dentro do prazo e verificada a regularidade do laudo, o juiz o declarará executório, conferindo-lhe fôrça de sentença, intimadas as partes.

\section{Nulidade da decisão arbitral}

16. Nula é a decisão arbitral, quando nulo é o compromisso; ou quando pronunciada fora dos limites do compromisso ou em desacôrdo com o seu objeto; quando nomeados os árbitros em desacôrdo com a forma prescrita, desde que a nulidade tenha sido argüida no juízo arbitral; quando infringente de direito expresso, salvo se, autorizado no compromisso, o julgamento tiver sido por equidade; quando contiver qualquer dos vícios que anulam as sentenças em geral; quando pronunciado fora do prazo assinado aos árbitros no compromisso; quando o laudo não fôr depositado no prazo do art. 1.043; e, finalmente, quando o laudo não satisfaça os requisitos enumerados no art. 1.038 do Código de Processo Civil. 


\section{Recurso de apelação}

17 Da sentença que homologar ou não o laudo arbitral cabe recurso de apelação (Cod. Proc. Civ. art. 1.046).

Qual o Tribunal competente para conliecer da apelação? No Estado de São Paulo há dois tribunais de segundo grau: o de Justiça e o de Alçada. Êste tem competência para as causas até o valor de $\mathrm{Cr} \$ 60.000,00$. Isso significa que, no Estado de São Paulo, diferentemente dos outros Estados, as partes devem fixar o valor da causa arbitral, para o efeito de determinar a competência do Tribunal em segundo grau que conhecerá do recurso de apelação.

Se o Tribunal anular o laudo, mandará que os árbitros julguem novamente a questão, salvo se negada a homologação com fundamento em nulidade de compromissos; havendo infração de direito expresso e não tendo os árbitros poder de decidir por equidade, o Tribunal aplicará à espécie o direito.

\section{Conclusão}

18. Eis ai as linhas fundamentais do instituto de juízo arbitral. A sua importância cresceu de tal modo nos ủltimos tempos que se criou em Paris uma comissão especial, destinada ao estudo de reforma do instituto. Já realizou dois Congressos, o primeiro em Paris e o segundo na Itália. A ampla discussão doutrinária nesses dois Congressos veio mostrar que, a despeito da experiência democrática do século XIX, que consagrou o princípio da separação dos poderes e o monopólio estatal da administração da justiça, as partes restabelecem a sua confiança no julgamento de seus pares, desprovidos de poder jurisdicional, especialmente porque, além das decisões conforme ao direito, o juizo arbitral pode, quando expressamente autorizado, julgar conforme a equidade, afim de realizar o ideal mais alto da justiça. 